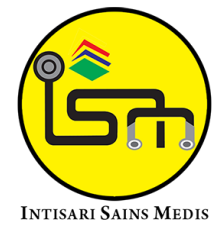

Published by Intisari Sains Medis

\section{Prevalensi dan persepsi disfagia pada populasi lanjut usia di Kota Denpasar periode September-Desember 2021}

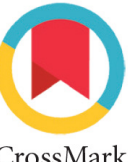

CrossMark

\author{
I Putu Santhi Dewantara ${ }^{1 *}$, I Wayan Sucipta ${ }^{1}$
}

'Departemen Ilmu Kesehatan Telinga Hidung Tenggorok Bedah Kepala Leher (THT-KL), Fakultas Kedokteran, Universitas Udayana, RSUP Sanglah, Bali, Indonesia

\section{*Korespondensi:}

I Putu Santhi Dewantara; Departemen IImu Kesehatan Telinga Hidung Tenggorok Bedah Kepala Leher (THT-KL), Fakultas Kedokteran, Universitas Udayana, RSUP Sanglah, Bali, Indonesia; santhidewantara@unud.ac.id
Diterima: 2021-11-02

Disetujui: 2021-12-06

Diterbitkan: 2021-12-29

\title{
ABSTRACT
}

Background: To investigate prevalence and perception of dysphagia in Denpasar City. The causes of dysphagia in the elderly include changes in the function and structure of the organs involved in the swallowing process, which are multifactorial. Dysphagia does affect not only the health aspect of the sufferer but also the social and economic aspects, especially in the elderly population. This study aims to determine the prevalence and perception of dysphagia in the elderly in Denpasar City.

Methods: This is a descriptive cross-sectional study that obtains data from the public health center in Denpasar City. Dysphagia was detected using the Swallowing Disturbances Questionaire (SDQ) and perception of dysphagia was obtained using direct questions. Data

were analyzed using SPSS version 21 for Windows. Results: 102 samples were obtained, with the most gender being female $(61.75 \%)$, and the age group was $60-69$ years old $(68.63 \%)$. A total of $11.76 \%$ of the sample stated that they had swallowing difficulties, while based on SDQ $10.78 \%$ had dysphagia. The most common comorbidities in the dysphagia group were head and neck malignancy (27.7\%) and hypertension (27.7\%), while in the non-dysphagic group were joint and skeletal disorders (34.09\%).

Conclusion: The prevalence of dysphagia in the elderly in Denpasar City is quite high, $10.78 \%$ based on SDQ and $11.76 \%$ based on the direct question. This requires special attention to overcome or prevent problems that may arise from dysphagia in the elderly.

Keywords: Dysphagia, Elderly, Prevalence, Perception

Cite This Article: Dewantara, I.P.S., Sucipta, I.W. 2021. Prevalensi dan persepsi disfagia pada populasi lanjut usia di Kota Denpasar periode September-Desember 2021. Intisari Sains Medis 12(3): 939-943. D0I: 10.15562/ism. v12i3.1186

\section{ABSTRAK}

Latar Belakang: Disfagia diartikan sebagai gangguan menelan saliva, makanan padat dan cair, termasuk obat-obatan. Penyebab disfagia pada lansia diantaranya adalah perubahan fungsi dan struktur organ yang terlibat dalam proses menelan yang bersifat multifaktorial. Disfagia tidak hanya mempengaruhi aspek kesehatan penderitanya, namun juga aspek sosial dan ekonominya terutama pada populasi lanjut usia. Penelitian ini bertujuan untuk mengetahui prevalensi dan persepsi disfagia pada lanjut usia di Kota Denpasar.

Metode: Penelitian ini menggunakan rancangan penelitian deskriptif potong lintang dengan mengambil data di puskesmas-puskesmas kota Denpasar menggunakan kuisioner. Disfagia dideteksi menggunakan Swallowing Disturbances Questionnaire (SDQ) sedangkan persepsi disfagia didapatkan dengan pertanyaan langsung. Data dianalisis dengan SPSS versi 21 untuk Windoes

Hasil: Didapatkan sampel sebanyak 102 orang, dengan jenis kelamin terbanyak adalah perempuan $(61,75 \%)$ dan rentang usia 60-69 tahun (68,63\%). Sebanyak $11,76 \%$ menyatakan mengalami gangguan menelan, sedangkan berdasarkan SDQ didapatkan 10,78\% mengalami disfagia. Penyakit penyerta terbanyak pada kelompok disfagia adalah keganasan kepala leher $(27,27 \%)$ dan hipertensi $(27,27 \%)$. Sedangkan pada kelompok tidak disfagia adalah gangguan sendi dan tulang $(34,09 \%)$. 
Kesimpulan: Prevalensi disfagia pada populasi lansia di Kota Denpasar cukup tinggi. Hal ini memerlukan perhatian khusus untuk mengatasi dan mencegah permasalahan yang dapat timbul akibat disfagia pada lansia.

Kata Kunci: Disfagia, Lanjut Usia, Prevalensi, Persepsi

Sitasi Artikel ini: Dewantara, I.P.S., Sucipta, I.W. 2021. Prevalensi dan persepsi disfagia pada populasi lanjut usia di Kota Denpasar periode September-Desember 2021. Intisari Sains Medis 12(3): 939-943. D0I: 10.15562/ism. v12i3.1186

\section{PENDAHULUAN}

Saat ini dunia berada dalam kondisi peningkatan populasi lanjut usia atau lansia. ${ }^{1}$ Pertumbuhan populasi lansia yang signifikan dapat diartikan sebagai perbaikan berbagai faktor seperti kesehatan, sosioekonomi, pendidikan, lingkungan, dan demografis yang menyebabkan peningkatan angka harapan hidup. ${ }^{2}$ Namun hal ini juga menimbulkan tantangan baru berupa meningkatnya masalah kesehatan yang dialami oleh lansia, salah satunya adalah disfagia. ${ }^{3}$

Disfagia diartikan sebagai gangguan menelan saliva, makanan padat dan cair, termasuk obat-obatan. ${ }^{4}$ Penyebab disfagia pada lansia diakibatkan oleh perubahan fungsi dan struktur organ yang terlibat dalam proses menelan akibat penuaan atau presbifagia, gangguan neurovaskular dan penyakit degeneratif, efek samping obatobatan, penyakit refluks gastroesofageal, infeksi, dan tumor yang mendesak saluran aerodigestif atas. ${ }^{4}$

Disfagia tidak hanya mempengaruhi aspek kesehatan penderitanya, namun juga aspek sosial dan ekonominya. Salah satu komplikasi yang paling berbahaya dari disfagia adalah aspirasi, yaitu masuknya bolus ke dalam saluran nafas. ${ }^{4,5}$ Aspirasi ini dapat terjadi tanpa refleks batuk atau silent aspiration, sehingga menyulitkan deteksinya. Efek aspirasi ini dapat menimbulkan pneumonia yang merupakan salah satu penyebab morbiditas dan mortalitas pada lansia. Makan dam minum juga merupakan aktivitas sosial dan pemuasan diri, sehingga disfagia akan sangat mempengaruhi aspek sosial dan psikologis penderitanya. Penderita disfagia memerlukan penatalaksanaan khusus, yang tentunya akan menimbulkan beban ekonomi tidak hanya bagi penderita itu sendiri, namun juga keluarganya. ${ }^{4,5}$

Prevalensi disfagia pada populasi lansia dilaporkan bervariasi dari 13,8\% hingga $20,1 \% .{ }^{6,7}$ Penelitian lain menemukan sekitar 50\% lansia yang dirawat mengalami gangguan menelan. ${ }^{8}$ Walau prevalensi disfagia pada lansia cukup banyak, sebagian besar penderitanya tidak mendapatkan penanganan yang tepat. Hal ini karena identifikasi yang kurang baik dan asumsi keluhan terkait disfagianya merupakan bagian normal dari penuaan, sehingga mereka tidak mencari pertolongan medis atau tidak menyebutkan keluhan terkait disfagia saat memeriksakan diri ke fasilitas kesehatan. ${ }^{4}$

Identifikasi disfagia menjadi sangat penting untuk mencegah komplikasi tersebut. Jika pasien tersedak saat makan atau segera setelah makan, diagnosis disfagia dapat dengan mudah ditegakkan. Namun identifikasi disfagia bisa cukup sulit pada lansia jika gejalanya tidak jelas dan pasien mengalami kesulitan wicara serta gangguan kognitif. ${ }^{4}$ Gejala disfagia tidak spesifik pada populasi lansia dan sifatnya berfluktuasi, seperti gangguan saat mengunyah, sisa makanan di rongga mulut, rasa mengganjal di tenggorok, batuk saat atau segera setelah makan, penurunan berat badan tanpa penyebab yang jelas, dan infeksi paru berulang. ${ }^{4}$

Berbagai metode telah dikembangkan untuk mengidentifikasi disfagia, mulai dari kuisioner untuk skrining, pemeriksaan fisik menelan, hingga pemeriksaan objektif dengan videofluoroskopi dan Flexible Endoscopic Evaluation of Swallowing (FEES). ${ }^{4}$ Pemeriksaan fisik menelan dan pemeriksaan objektif memakai videofluoroskopi atau FEES mungkin sulit dilakukan pada kondisi tertentu dan dapat memberikan ketidaknyamanan bagi pasien, sehingga pemeriksaanpemeriksaan ini tidak dapat dikerjakan pada semua pasien. ${ }^{9}$

Beberapakuisionertelahdikembangkan untuk mengidentifikasi disfagia. Swallowing Disturbance Questionnaire (SDQ) merupakan kuisioner yang terdiri dari 15 pertanyaan mencakup gangguan yang terjadi pada fase oral dan faringeal. ${ }^{9}$ Kuisioner ini dapat dijawab sendiri oleh pasien atau dibacakan oleh orang lain, sehingga cukup mudah diisi. Skor total SDQ $>12,5$ merupakan prediktor adanya gangguan menelan, baik yang diketahui maupun tidak diketahui. Kuisioner ini berkorelasi baik dengan pemeriksaan oromotor dan FEES, dengan sensitivitas $79,7 \%$ dan spesifisitas $73,0 \%{ }^{9}$

Data mengenai prevalensi disfagia di Indonesia khususnya di Denpasar belum tersedia dengan baik sehingga beban kesehatan yang muncul juga belum diketahui. Selain itu, identifikasi disfagia orofaring bisa menjadi cukup sulit karena memerlukan pemeriksaan yang spesifik dan persepsi lansia yang menganggap keluhan terkait disfagia merupakan bagian normal dari proses menua yang mereka alami. Berdasarkan pemaparan di atas maka penelitian ini bertujuan untuk mengetahui prevalensi dan persepsi disfagia pada lanjut usia di Kota Denpasar.

\section{METODE}

Penelitian ini merupakan penelitian potong lintang (Cross-Sectional) deskriptif pada populasi lansia di Kota Denpasar. Penelitian dilakukan dengan melakukan wawancara menggunakan kuisioner pada saat pertemuan lansia yang dilakukan oleh petugas puskesmas dan sebagian lagi dilakukan wawancara melalui telepon. Kontak lansia didapatkan dari puskesmas- 
puskesmas di Kota Denpasar. Data yang dikumpulkan meliputi nama, usia, jenis kelamin, persepsi mengenai disfagia, skor SDQ, dan penyakit penyerta. Penelitian ini dilakukan di Kota Denpasar pada bulan September hingga Oktober 2021. Populasi target adalah seluruh lansia di Kota Denpasar. Populasi terjangkau adalah lansia yang bertempat tinggal di Kota Denpasar, yang mendatangi pertemuan lansia yang diadakan oleh puskesmas, dan lansia yang kontaknya didapatkan dari puskesmas di Kota Denpasar. Sampel penelitian adalah lansia yang bertempat tinggal di Kota Denpasar, mendatangi pertemuan lansia rutin puskesmas, dan yang kontaknya didapatkan dari puskesmas di Kota Denpasar. Kriteria inklusi adalah lansia yang bertempat tinggal di Kota Denpasar dan kontaknya didapatkan dari puskesmas di Kota Denpasar, laki-laki dan perempuan, warga negara Indonesia, keadaan umum baik, dan bersedia ikut serta dalam penelitian dan Kriteria ekslusi adalah individu dengan kondisi umum yang buruk, tidak bersedia ikut penelitian, dan yang tidak lengkap mengisi kuisioner.

Analisis data pada penelitian ini terdiri dari analisis statistik deskriptif, uji normalitas, menggunakan SPSS 21 untuk Windows. Analisis statistik deskriptif bertujuan untuk menggambarkan karakteristik subjek dan variabel penelitian secara keseluruhan. Variabel berskala data numerik (rasio) ditampilkan menggunakan rerata dan standar deviasi jika berdistribusi normal. Jika tidak berdistribusi normal, menggunakan median dan interquartile range. Variabel yang berskala data kategorikal ditampilkan menggunakan frekuensi relatif (jumlah dan persen). Uji normalitas bertujuan untuk menilai sebaran data variabel berskala data numerik (rasio) apakah berdistribusi normal atau tidak, menggunakan uji normalitas Kolmogorov Smirnov.

\section{HASIL}

Berdasarkan hasil penelitian ini (Tabel 1), didapatkan sampel laki-laki sejumlah 39 orang $(38,24 \%)$ dan sampel perempuan sebanyak 63 orang $(61,74 \%)$. Rentang usia sampel antara 60-69 tahun sebanyak 70 orang (68.63\%), 70-79 tahun sebanyak 29 orang $(28.43 \%)$, dan $>80$ tahun sebanyak 3 orang (2.94\%).

Berdasarkan data Tabel 2 didapatkan sebanyak 12 orang $(11,76 \%)$ mengeluhkan adanya gangguan menelan/ disfagia berdasarkan pertanyaan langsung, sedangkan sebanyak 90 orang $(88,24 \%)$ tidak mengeluhkan adanya disfagia. Sebanyak 11 orang $(10,78 \%)$ mendapatkan skor $\mathrm{SDQ} \geq 12,5$, yang menunjukkan pasien kemungkinan mengalami disfagia, baik yang disadari maupun tidak disadari oleh individu tersebut. Jumlah sampel tanpa disfagia (skor SDQ $<12,5$ ) sebanyak 90 orang $(88,24 \%)$. Dari 11 orang dengan disfagia (skor SDQ $\geq 12,5$ ), sebanyak 6 orang (54,55\%) menyatakan mengalami disfagia, dan sebanyak 5 orang $(45,45 \%)$ menyatakan tidak mengalami disfagia. Sedangkan dari 91 orang tanpa disfagia (skor SDQ <12,5) sebanyak 6 orang $(6,59 \%)$ menyatakan mengalami

Tabel 1. Distribusi sampel penelitian berdasarkan jenis kelamin dan usia

\begin{tabular}{ccc}
\hline Variabel & Total $(\mathbf{N}=\mathbf{1 0 2})$ & Persentase (\%) \\
\hline Jenis Kelamin & & \\
Laki-laki & 39 & 38,24 \\
Perempuan & 63 & 61,74 \\
Usia (Tahun) (rerata \pm SB) & $67,13 \pm 6,54$ & \\
$60-69$ & 70 & 68,63 \\
$70-79$ & 29 & 28,43 \\
$>80$ & 3 & 2,94 \\
\hline
\end{tabular}

SB: Simpang Baku

Tabel 2. Distribusi sampel penelitian berdasarkan persepsi disfagia dan skor Swallowing Disturbances Questionnaires (SDQ)

\begin{tabular}{|c|c|c|c|}
\hline \multirow[b]{2}{*}{ Variabel } & \multicolumn{2}{|c|}{ Skor SDQ $(\mathrm{N}=102)$} & \multirow[b]{2}{*}{ Total } \\
\hline & $\begin{array}{c}\text { Disfagia } \\
(\mathrm{SDQ} \geq 12.5) \\
(\mathrm{N}=11)\end{array}$ & $\begin{array}{c}\text { Tidak disfagia } \\
\text { (SDQ <12.5) } \\
(\mathrm{N}=91)\end{array}$ & \\
\hline \multicolumn{4}{|l|}{ Persepsi Disfagia, n (\%) } \\
\hline Mengalami disfagia & $6(5,88)$ & $6(5,88)$ & $12(11,76)$ \\
\hline Tidak mengalami disfagia & $5(4,90)$ & $85(83,34)$ & $90(88,24)$ \\
\hline \multicolumn{4}{|l|}{ Jenis Kelamin, n (\%) } \\
\hline Laki-laki & $7(63,64)$ & $32(35,16)$ & $39(38,24)$ \\
\hline Perempuan & $4(36,36)$ & $59(64,84)$ & $63(61,76)$ \\
\hline Usia (Tahun) (rerata \pm SB), n (\%) & $65,63 \pm 4.82$ & $67,31 \pm 6.65$ & \\
\hline $60-69$ & $8(72,73)$ & $62(68,13)$ & $70(68,63)$ \\
\hline $70-79$ & $3(27,27)$ & $26(28,57)$ & $29(28,43)$ \\
\hline$>80$ & $(0,00)$ & $3(3,30)$ & $3(2,94)$ \\
\hline
\end{tabular}

SB: Simpang Baku; SDQ: Swallowing Disturbances Questionnaires

Tabel 3. Distribusi penyakit penyerta pada kelompok disfagia dan tidak disfagia

\begin{tabular}{lcc}
\hline \multicolumn{1}{c}{ Penyakit Penyerta } & $\begin{array}{c}\text { Disfagia } \\
(\mathbf{N = 1 1 )}\end{array}$ & $\begin{array}{c}\text { Tidak Disfagia } \\
\mathbf{( N = 4 4 )}\end{array}$ \\
\hline Diabetes melitus & $1(9,09)$ & $12(27,27)$ \\
Hipertensi & $3(27,27)$ & $6(13,64)$ \\
Keganasan kepala leher & $3(27,27)$ & $0(0,00)$ \\
Stroke & $0(0,00)$ & $2(4,55)$ \\
Gangguan tulang dan sendi & $1(9,09)$ & $15(34,09)$ \\
Lainnya & $3(27,27)$ & $9(20,45 \%)$ \\
\hline
\end{tabular}


disfagia, dan sebanyak 85 orang $(93,41 \%)$ menyatakan tidak mengalami disfagia (Tabel 2).

Subjek dengan disfagia sebagian besar berjenis kelamin laki-laki (Tabel 2), yaitu sebanyak 7 orang $(63,64 \%)$ sedangkan kelompok tidak disfagia sebagian besar berjenis kelamin perempuan, yaitu sebanyak 59 orang $(64,84 \%)$. Rerata umur kelompok subjek dengan disfgaia adalah 65,63 tahun sedangkan kelompok subjek tidak disfagia memiliki rerata umur 67,31 tahun.

Sebanyak 8 orang $(72,73 \%)$ subjek dengan disfagia memiliki penyakit penyerta, sedangkan pada kelompok subjek tidak disfagia didapatkan 22 orang $(24,18 \%)$ yang memiliki penyakit penyerta. Distribusi penyakit penyerta pada masing-masing kelompok ditampilkan pada Tabel 3. Penyakit penyerta terbanyak pada kelompok disfagia adalah keganasan kepala leher $(27,27 \%)$ dan hipertensi (27,27\%). Sedangkan pada kelompok tidak disfagia adalah gangguan sendi dan tulang (34,09\%) (Tabel 3).

\section{PEMBAHASAN}

Penelitian ini mendapatkan 11,76\% sampel memiliki persepsi bahwa dirinya mengalami disfagia berdasarkan pertanyaan secara langsung, sedangkan prevalensi disfagia berdasarkan skrining menggunakan SDQ pada penelitian ini didapatkan sebesar 10,78\%. Hasil penelitian ini berbeda dengan hasil penelitian Chen $\mathrm{PH}$ et al., yang melaporkan prevalensi disfagia berdasarkan kuisioner skrining menggunakan $M D$ Anderson Dysphagia Inventory (MDADI) lebih tinggi (15,9\%) dibandingkan dengan persepsi disfagia berdasarkan pertanyaan langsung (15,0\%). ${ }^{10}$ Prevalensi disfagia berdasarkan pertanyaan langsung pada penelitian ini lebih rendah dibandingkan dengan prevalensi disfagia berdasarkan kuisioner mungkin disebabkan oleh perbedaan pengetahuan masing-masing individu mengenai gangguan menelan sehingga saat ditelusuri secara terstruktur menggunakan SDQ hasilnya berbeda dan perbedaan jenis kuisioner yang digunakan dengan penelitian sebelumnya.

Sebanyak 5 orang $(45,45 \%)$ dengan skor $\mathrm{SD}>12,5$ tidak memiliki persepsi bahwa dirinya mengalami disfagia.
Hal ini mungkin diakibatkan karena individu tersebut tidak mengetahui gejala yang dideritanya merupakan bagian dari disfagia. Gejala klinis disfagia tidak spesifik dan berfluktuasi pada lansia, sehingga menyebabkan kesulitan identifikasi disfagia. ${ }^{4}$

Prevalensi disfagia pada lansia penelitian ini tidak jauh berbeda dengan prevalensi yang didapatkan oleh Chaleekrua $S$ et al., yang melaporkan sebesar 11,4\% dan Kawashima K et al., sebesar 13,8\%.711 Namun penelitian oleh Khader FA et al., yang juga menggunakan SDQ mendapatkan prevalensi disfagia pada lansia sebesar 20,1\%.6 Prevalensi yang lebih tinggi ini mungkin diakibatkan karena penelitian oleh Khader FA et al., dilakukan di rumah sakit tersier yang merupakan fasilitas rujukan tingkat lanjut, sehingga kasus-kasus disfagia lebih sering ditemui. ${ }^{6}$ Sedangkan penelitian ini merupakan penelitian berbasis komunitas yang mengambil sampel lansia di masyarakat.

Berdasarkan penelitian ini, disfagia memiliki prevalensi yang cukup besar pada populasi lansia di masyarakat, khususnya Kota Denpasar. Deteksi dini diperlukan untuk mencegah komplikasi yang dapat timbul, seperti aspirasi, penumonia, malnutrisi, dan bahkan kematian. Pemeriksaan objektif seperti FEES atau videofluoroskopi relatif mahal dan tidak praktis untuk dikerjakan di fasilitas kesehatan primer. Skrining menggunakan kuisioner seperti SDQ dapat menjadi langkah pertama untuk deteksi dini disfagia pada lansia, selanjutnya lansia yang dicurigai mengalami disfagia dapat dirujuk untuk pemeriksaan dan penanganan lebih lanjut.

Studi yang dilakukan oleh Dantas RO et al., melaporkan kemungkinan adanya efek jenis kelamin dan usia terhadap fungsi menelan pada individu yang sehat. ${ }^{12}$ Wanita menunjukkan transit orofaring, penutupan laring selama menelan, dan durasi bukaan sfingter atas esofagus yang lebih lama dibandingkan laki-laki. ${ }^{12}$ Selain itu, volume bolus dan interval setiap menelan lebih kecil/pendek dibandingkan dengan laki-laki. Pertambahan usia menyebabkan penurunan tekanan lidah, penurunan diskriminasi sensorik faring, peningkatan ambang rangsang pemicu fase faringeal, pemanjangan fase orofaring, keterlambatan sebelum onset respon fase faringeal, dan peningkatan residu dalam faring. ${ }^{6}$ Perbedaan proses menelan antara laki-laki dan perempuan ini terlihat lebih jelas pada usia kurang dari 40 tahun. Perubahan proses menelan pada lansia jauh lebih intens pada laki-laki dibandingkan perempuan, dan setelah berumur 60 tahun, proses menelan antara laki-laki dan perempuan relatif serupa. ${ }^{12}$

Hasil penelitian ini menunjukkan lakilaki $(63,64 \%)$ lebih banyak mengalami disfagia dibandingkan perempuan pada penelitian ini. Hal ini sesuai dengan penelitian oleh Khader FA et al., yang mendapatkan sebanyak $61,5 \%$ subjek dengan disfagia adalah laki-laki. ${ }^{6}$ Sedangkan studi yang dilakukan oleh ChaleekruaS et al., melaporkan perempuan lebih banyak mengalami disfagia (63\%) dibandingkan dengan laki-laki (37\%). ${ }^{11}$ Akan tetapi studi lain yang dilakukan oleh Khader FA et al., dan Chaleekrua $S$ et al., tidak mendapatkan korelasi antara jenis kelamin dan disfagia. ${ }^{6,11}$

Prevalensi disfagia diperkirakan meningkat dengan bertambahnya usia, namun hasil penelitian ini menunjukkan prevalensi disfagia tertinggi pada rentang usia 60-69 tahun (72,83\%), sedangkan rentang usia di atasnya lebih rendah. Khader FA et al., mendapatkan prevalensi disfagia terbanyak pada rentang usia 6170 tahun $(76,9 \%) .{ }^{6}$ Studi yang dilakukan sebelumnya oleh Chaleekrua $S$ et al., mendapatkan rentang usia 70-79 tahun sebagai kelompok yang terbanyak mengalami disfagia (49\%). ${ }^{11}$ Prevalensi disfagia tertinggi terjadi pada rentang usia lansia yang paling rendah pada penelitian ini mungkin diakibatkan karena subjek pada rentang usia tersebut memiliki penyakit penyerta yang menimbulkan disfagia dan jumlah subjek yang berusia $\geq 70$ tahun lebih sedikit dibandingkan dengan subjek pada rentang usia 60-69 tahun.

Sebesar $72,73 \%$ subjek dengan disfagia memiliki penyakit penyerta, jauh lebih besar dibandingkan pada kelompok subjek tidak disfagia yang hanya $24,18 \%$. Dua penyakit terbanyak yang diderita adalah keganasan kepala leher dan hipertensi. Keganasan kepala leher dapat menyebabkan disfagia, baik karena 
penyakit itu sendiri maupun akibat dari terapinya (pembedahan, kemoterapi, dan radioterapi). ${ }^{13}$ Hipertensi jarang menyebabkan disfagia secara langsung, namun ada satu bentuk disfagia dapat diakibatkan oleh hipertensi, yaitu disfagia aortika. Disfagia aortika merupakan gangguan menelan akibat kompresi esofagus oleh aorta yang mengalami anomali, seperti aneurisma aorta, diseksi aorta, dan aorta yang berliku (tortuous aorta). Aorta yang berliku ini diasosiasikan dengan hipertensi. ${ }^{14}$ Penelitian ini tidak mendapatkan lansia dengan disfagia yang menderita stroke ataupun penyakit degeneratif seperti Alzheimer dan Parkinson. Penderita stroke dan penyakit degeneratif juga dilaporkan sebagian besar mengalami disfagia. ${ }^{15,16}$

\section{SIMPULAN}

Prevalensi disfagia pada populasi lansia di Kota Denpasar cukup tinggi, yaitu sebesar $10,78 \%$ berdasarkan SDQ dan sebanyak $11,76 \%$ populasi lansia menyatakan mengalami gangguan menelan. Hal ini memerlukan perhatian khusus dari berbagai pihak untuk mencegah permasalahan yang dapat timbul akibat disfagia, tidak hanya dari sisi kesehatan, namun juga sisi sosial dan ekonomi.

\section{KONFLIK KEPENTINGAN}

Penulis menyatakan tidak terdapat konflik kepentingan pada penulisan laporan ini.

\section{PERSETUJUAN ETIK}

Penelitian ini mendapat persetujuan dari Komisi Etik Fakultas Kedokteran
Universitas Udayana/RSUP Sanglah Denpasar 2055/UN14.2.2VII.14/LT/2021

\section{PENDANAAN}

Penelitian ini mendapatkan dana dari Kementerian Pendidikan, Kebudayaan, Riset dan Teknologi, Fakultas KedokteranUniversitas Udayana program Skema Unggulan Dosen Muda dengan nomor SK: B/5169-3/UN14.2.2.VII.1/PT.01.03/2021

\section{KONTRIBUSI PENULIS}

I Putu Santhi Dewantara bertanggung jawab terhadap pengumpulan data, analisis data, penyusunan naskah penelitian. I Wayan Sucipta berperan dalam analisis data dan penuntunan metodologi penelitian.

\section{DAFTAR PUSTAKA}

1. Kanasi E, Ayilavarapu S, Jones J. The aging population: demographics and the biology of aging. Periodontol 2000. 2016;72(1):13-18.

2. Dello Buono M, Urciuoli O, De Leo D. Quality of life and longevity: a study of centenarians. Age Ageing. 1998;27(2):207-216.

3. Aslam M, Vaezi MF. Dysphagia in the elderly. Gastroenterol Hepatol (N Y). 2013;9(12):784-795.

4. Foster A, Samaras N, Gold G, Samaras D. Oropharyngeal Dysphagia in Older Adults: A Review. European Geriatric Medicine. 2011;2(6):356-362.

5. Wirth R, Dziewas R, Beck AM, Clavé P, Hamdy $\mathrm{S}$, Heppner HJ, et al. Oropharyngeal dysphagia in older persons - from pathophysiology to adequate intervention: a review and summary of an international expert meeting. Clin Interv Aging. 2016;11:189-208.

6. Khader FA, Somayaji KSG, Mubeena. Swallowing Difficulties Among Healthy Elderly: Prevalence and Aetiology. International Journal of Otorhinolaryngology and Head and Neck
Surgery. 2018;4(2):494-498.

7. Kawashima K, Motohashi Y, Fujishima I. Prevalence of dysphagia among communitydwelling elderly individuals as estimated using a questionnaire for dysphagia screening. Dysphagia. 2004;19(4):266-271.

8. Rofes L, Arreola V, Almirall J, Cabré M, Campins L, García-Peris P, et al. Diagnosis and management of oropharyngeal Dysphagia and its nutritional and respiratory complications in the elderly. Gastroenterol Res Pract. 2011;2011:818979.

9. Cohen JT, Manor Y. Swallowing disturbance questionnaire for detecting dysphagia. Laryngoscope. 2011;121(7):13831387.

10. Chen PH, Golub JS, Hapner ER, Johns MM 3rd. Prevalence of perceived dysphagia and quality-of-life impairment in a geriatric population. Dysphagia. 2009;24(1):1-6.

11. Chaleekrua S, Janpol K, Wattanapan P. Swallowing Problems among CommunityDwelling Elderly in Northeastern Thailand. J Prim Care Community Health. 2021;12:21501327211019596.

12. Dantas RO, Alves LM, Santos CM, Cassiani Rde A. Possible interaction of gender and age on human swallowing behavior. Arq Gastroenterol. 2011;48(3):195-198.

13. Baijens LWJ, Walshe M, Aaltonen LM, Arens C, Cordier R, Cras P, et al. European white paper: oropharyngeal dysphagia in head and neck cancer. Eur Arch Otorhinolaryngol. 2021;278(2):577-616.

14. Abdul Haziz SR, Bickle I, Chong VH. Dysphagia aortica: a rare cause of dysphagia. BMJ Case Rep. 2015;2015:bcr2015211726.

15. Abdel Jalil AA, Katzka DA, Castell DO. Approach to the patient with dysphagia. Am J Med. 2015;128(10):1138.e17-23.

16. Cabre M, Serra-Prat M, Palomera E, Almirall J, Pallares R, Clavé P. Prevalence and prognostic implications of dysphagia in elderly patients with pneumonia. Age Ageing. 2010;39(1):3945 .

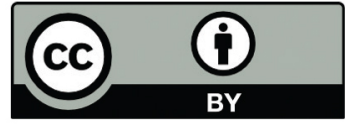

This work is licensed under a Creative Commons Attribution 